\title{
ARTICLE
}

\section{Effects of Hypoxia on Consumption, Growth, and RNA:DNA Ratios of Young Yellow Perch}

\author{
James J. Roberts ${ }^{1}$ \\ School of Natural Resources and Environment, University of Michigan, Ann Arbor, Michigan, USA; \\ Cooperative Institute for Limnology and Ecosystems Research, University of Michigan, Ann Arbor, \\ Michigan, USA; and the National Oceanic and Atmospheric Administration-Great Lake Environmental \\ Research Laboratory, 4840 South State Road, Ann Arbor, Michigan 48108-9719, USA
}

\section{Stephen B. Brandt}

Oregon Sea Grant Program, Oregon State University, 322 Ker Administration Building, Corvallis, Oregon 97331-2131, USA

\section{David Fanslow}

National Oceanic and Atmospheric Administration-Great Lake Environmental Research Laboratory, 4840 South State Road, Ann Arbor, Michigan 48108-9719, USA

\section{Stuart A. Ludsin}

Aquatic Ecology Laboratory, Department of Ecology, Evolution, and Organismal Biology,

The Ohio State University, 1314 Kinnear Road, Columbus, Ohio 43212, USA

\section{Steven A. Pothoven}

National Oceanic and Atmospheric Administration-Great Lake Environmental Research Laboratory, 1431 Beach Street, Muskegon, Michigan 49441-1098, USA

\section{Donald Scavia}

School of Natural Resources and Environment, University of Michigan, 625 East Liberty Street, Suite 300, Ann Arbor, Michigan 48104, USA

\section{Tomas O. Höök*}

Department of Forestry and Natural Resources, Purdue University, 195 Marstellar Street, West Lafayette, Indiana 47907, USA

\begin{abstract}
As in various freshwater and coastal marine ecosystems worldwide, seasonal bottom water hypoxia is a recurring phenomenon in Lake Erie's central basin. While bottom hypoxia can strongly affect sessile benthic animals, its effects on mobile organisms such as fish are less understood. We evaluated the potential for bottom hypoxia to affect the growth rates of yellow perch Perca flavescens, a species of ecological and economic importance in the lake. To this end, we (1) conducted laboratory experiments to quantify the effects of reduced dissolved oxygen on consumption, somatic growth, and RNA:DNA ratios (an index of short-term growth) of young yellow perch and (2) explored the effects of bottom hypoxia on young yellow perch growth in Lake Erie's central basin by collecting individuals in hypoxic
\end{abstract}

*Corresponding author: thook@purdue.edu

${ }^{1}$ Present address: Department of Fish, Wildlife and Conservation Biology, Colorado State University, 1484 Campus Delivery, Fort Collins, Colorado 80523, USA.

Received August 20, 2010; accepted May 19, 2011

Published online December 7, 2011 
and normoxic regions of the lake and quantifying their RNA:DNA ratios. Yellow perch consumption and growth in our experiments declined under hypoxic conditions $(\leq 2 \mathrm{mg} \mathrm{O} / \mathrm{L})$. While yellow perch RNA:DNA ratios responded strongly to experimental temperature, nucleic acid ratios were not significantly affected by dissolved oxygen or feeding ration. We did, however, observe a positive correlation between yellow perch growth and RNA:DNA ratios at low temperatures $\left(11^{\circ} \mathrm{C}\right)$. The nucleic acid ratios of yellow perch collected in Lake Erie varied spatiotemporally, but their patterns were not consistent with hypoxia. In short, while yellow perch consumption and growth rates respond directly and negatively to low oxygen conditions, these responses are not necessarily reflected in RNA:DNA ratios. Moreover, in central Lake Erie, where yellow perch can behaviorally avoid hypoxic areas, the RNA:DNA ratios of yellow perch do not respond strongly to bottom hypoxia. Thus, this study suggests that there is no strong negative effect of bottom hypoxia on the growth of young yellow perch in Lake Erie.

Hypoxia ( $\leq 2 \mathrm{mg} \mathrm{O}_{2} / \mathrm{L}$ ) is a recurring phenomena in both marine and freshwater ecosystems worldwide (Diaz 2001; Diaz and Rosenberg 2008). Previous studies have demonstrated that hypoxia can influence fish distributions, foraging behavior, and food web interactions both directly and indirectly (e.g., Pihl 1994; Eby and Crowder 2002; Craig and Crowder 2005; Roberts et al. 2009). However, the direct and indirect effects of hypoxia on fish growth are less clear (but see Stewart et al. 1967; Brandt et al. 2009).

While laboratory experiments have demonstrated the direct effects of low oxygen concentrations on fish physiology (Kramer 1987; Thomas et al. 2005; Stierhoff et al. 2006), the effects of hypoxia are less evident in natural ecosystems because many fishes can detect and avoid hypoxic areas. For example, in the laboratory low dissolved oxygen concentrations may lead to responses such as increased ventilation (Petrosky and Magnuson 1973; Suthers and Gee 1986; Ludsin et al. 2009) and can negatively influence food consumption (hereafter referred to as consumption) and growth of fishes (e.g., Stewart et al. 1967; Brandt et al. 2009). In natural systems, avoidance of hypoxic conditions can influence distributions of fishes (e.g., Suthers and Gee 1986; Ludsin et al. 2009) and indirectly affect diet patterns (Pihl 1994; Aku et al. 1997; Taylor et al. 2007). While such effects on diet and movement of fish into novel habitats may be expected to influence growth, few field studies have demonstrated hypoxia-induced growth consequences for fish in natural systems (e.g., Eby et al. 2005; Stierhoff et al. 2009).

Traditional methods of examining fish growth (e.g., chronometric structures) integrate responses to environmental conditions over long periods (e.g., annually, lifetime). Such methods are, however, not ideal for examining growth responses to hypoxia, given the relatively short persistence (hours to months) of hypoxia in most systems. Nucleic acid ratios (RNA:DNA ratios) are useful indices of short-term growth and have been used to examine short-term growth of various aquatic organisms such as zooplankton (Gorokhova and Kyle 2002; Gorokhova 2003), larval fish (Clemmesen 1994; Pepin et al. 1999; Höök et al. 2008), and juvenile and adult fish (Gwak et al. 2003; Smith and Buckley 2003; Stierhoff et al. 2009) including yellow perch Perca flavescens (Audet and Couture 2003; Tardif et al. 2005; Glemet and Rodriguez 2007), our study species.
Whereas DNA concentrations in cells are relatively static, RNA concentrations are more dynamic with greater amounts of RNA indicating increased protein synthesis and therefore increased growth (Bulow 1987). Ratios of RNA to DNA are sensitive to temperature because for most fish species, more RNA is required at lower temperatures than at higher temperatures to induce similar metabolic and growth rates (Buckley 1982; Goolish et al. 1984). Several laboratory studies have developed speciesand temperature-specific positive relationships between growth and RNA:DNA ratios (Clemmesen 1994; Grant 1996; Ali and Wootton 2003; MacLean and Caldarone 2008; Stierhoff et al. 2009), thereby facilitating a positive linkage between RNA: DNA ratios and somatic growth.

We focused our study on the growth consequences of hypoxia for yellow perch in Lake Erie's central basin (LECB). Yellow perch are an ecologically and economically important fish species in LECB (Ryan et al. 2003), a system that frequently experiences hypolimnetic hypoxia during late summer (Edwards et al. 2005; Hawley et al. 2006; Rao et al. 2008). Carlson et al. (1980) demonstrated through laboratory experiments that yellow perch growth declines when the dissolved oxygen concentration approaches $2 \mathrm{mg} / \mathrm{L}$ at about $20^{\circ} \mathrm{C}$. Thus, while prolonged, direct exposure of yellow perch to low oxygen should negatively affect growth at $20^{\circ} \mathrm{C}$, the direct effects of low dissolved oxygen on yellow perch consumption, growth, and RNA:DNA ratios at diverse temperatures remain understudied. Elucidating the ecological impacts of hypolimnetic hypoxia in LECB is particularly important because hypoxia recurs annually in Lake Erie and can cover a very large portion of the basin (in 2005 the hypoxic zone was estimated to cover $10,000 \mathrm{~km}^{2}$, Hawley et al. 2006). A recent field study demonstrated that bottom hypoxia could alter patterns of habitat use (i.e., reduced use of bottom waters) and foraging (i.e., reduced consumption of benthic macroinvertebrates and increased consumption of zooplankton) of yellow perch in LECB (Roberts et al. 2009). Increased occupation of relatively warm, epilimnetic waters should increase metabolic demands, and increased consumption of small, energetically inferior zooplankton prey may result in reduced growth rates. Thus, we hypothesized that bottom hypoxia should also indirectly negatively affect growth of yellow perch in LECB. 
The combined use of laboratory experiments, targeted field sampling, and relevant measures that can capture short-term changes in growth dynamics (i.e., RNA:DNA ratios) offers an integrative approach to determine whether hypoxia affects fish growth. To this end, we conducted a field- and laboratory-based study to evaluate the effects of hypoxia on short-term growth of young yellow perch. Specifically, our study included three objectives. (1) We evaluated the effectiveness of RNA:DNA ratios as a measure of short-term growth for yellow perch in the laboratory. As demonstrated by previous studies (Clemmesen 1994; Grant 1996; Ali and Wootton 2003; MacLean and Caldarone 2008; Stierhoff et al. 2009), temperature-specific relationships between RNA:DNA ratios and somatic growth can be used to infer somatic growth of field-collected fish by measuring their RNA:DNA ratios. While previous studies have used RNA:DNA ratios to infer growth of yellow perch collected from the wild (Audet and Couture 2003; Tardif et al. 2005; Glemet and Rodriguez 2007), to our knowledge these corroboration experiments have not been conducted for yellow perch. (2) We quantified the interactive effects of direct exposure to temperature and dissolved oxygen concentrations on young yellow perch growth and consumption in the laboratory. While yellow perch in LECB may behaviorally avoid low oxygen concentrations (Roberts et al. 2009), demonstrating the direct effects of low oxygen on growth elucidates the consequences if yellow perch were to remain in hypoxic waters. Similarly, quantifying temperature and dissolved oxygen effects on yellow perch consumption should facilitate understanding of hypoxia effects because consumption is an important driver of growth and a central component of fish bioenergetics models (i.e., Kitchell et al. 1977). (3) Finally, after evaluating the use of RNA :DNA ratios to index growth of young yellow perch, we investigated the potential effects of hypoxia on RNA:DNA ratios of young yellow perch inhabiting LECB. Given that young yellow perch in LECB behaviorally avoid low oxygen environments (Roberts et al. 2009), the potential effects of hypoxia are likely to be indirect. To this end, during 2005 and 2007 we compared RNA:DNA ratios among young yellow perch collected in areas of LECB with hypoxic and normoxic hypolimnia.

\section{METHODS}

Laboratory experiments.-We conducted two separate controlled laboratory experiments: one to quantify the effectiveness of the RNA:DNA ratio as a measure of short-term somatic growth by examining how feeding rate and temperature influence young yellow perch growth and RNA:DNA ratios, and a second experiment to quantify how temperature and dissolved oxygen concentration independently and interactively affect yellow perch consumption, growth, and RNA:DNA ratios. Experiments were conducted at the Michigan Department of Natural Resources' Saline Fisheries Research Station. We obtained juvenile (i.e., age 1) yellow perch (100-180 mm total length [TL]) from a local fish hatchery, housed them in holding tanks, and fed them thawed Mysis relicta ad libitum until the experiments began. Experimental chambers consisted of two compartments approximately $18 \mathrm{~L}$ in size within a single $40-\mathrm{L}$ tank. Compartments were separated by two, opaque, mesh plastic sheets, between which were housed a heater, air stones, and an underwater internal filter (Fluval 1 Plus). Each experimental tank also contained a copper cooling coil buried underneath a bottom substrate layer $(\sim 30 \mathrm{~mm})$ of sand. In low temperature $\left(11^{\circ} \mathrm{C}\right)$ treatment tanks, these cooling coils were connected to chiller units. In the medium $\left(20^{\circ} \mathrm{C}\right)$ and high $\left(26^{\circ} \mathrm{C}\right)$ temperature treatment tanks, cooling coils were not connected to chillers. We manipulated dissolved oxygen concentrations by injecting combinations of nitrogen and atmospheric gas through air stones until the desired dissolved oxygen concentrations were obtained. We measured and recorded the temperature $\left({ }^{\circ} \mathrm{C}\right), \mathrm{pH}$, and dissolved oxygen (DO) concentration $\left(\mathrm{mg} \mathrm{O}_{2} / \mathrm{L}\right)$ of each experimental tank once daily with an Accumet Portable $\mathrm{PH} /{ }^{\circ} \mathrm{C}$ meter and YSI model 55 DO system, respectively.

At the beginning of each experiment, randomly selected individual yellow perch were removed from holding tanks, measured (TL to nearest $1 \mathrm{~mm}$ and blotted wet mass to nearest $0.01 \mathrm{~g}$ ), and placed in experimental compartments. We placed two fish in each tank on opposite sides of the plastic mesh dividers. While the two yellow perch in each tank did not interact directly, we used mean tank observations (i.e., the average of both fish in a given tank) as our sample unit, taking a conservative approach to avoid possible pseudoreplication (Hurlbert 1984). Experiments consisted of three tank-acclimation days, followed by five experimental days. We fed fish thawed $M$. relicta on acclimation day 1 and then starved them during acclimation days 2 and 3. During experimental days, we left food in the tank chambers for $6 \mathrm{~h}$ (from 0900 to 1500 hours), and then removed (using small aquarium nets), blotted dry, and weighed (to nearest $0.01 \mathrm{~g}$ ) the remaining food. We determined consumption by measuring the difference between the amount of food introduced to the tank chamber and the amount of food remaining uneaten after $6 \mathrm{~h}$. To correct these measures of remaining food for loss of material to solution, we multiplied the remaining amount of food by temperature-specific correction factors (Roberts 2010). While Roberts (2010) found no difference in consumption rates among experimental days 35 , consumption during experimental day 1 (following $2 \mathrm{~d}$ of starvation) and experimental day 2 were greater and less, respectively, than during other experimental days. Thus, feeding rates during experimental days 1 and 2 were not indicative of potential long-term maximum feeding rates under experimental conditions. Hence, to calculate mean consumption for individual fish, we averaged observed consumption during experimental days $3-5$.

After the 6-h feeding trials on experimental day 5, we removed and anesthetized each experimental individual and recorded individual TL (to $1 \mathrm{~mm}$ ) and mass (to $0.01 \mathrm{~g}$ ). To determine RNA:DNA ratios, we extracted white epaxial muscle tissue $(\sim 40 \mathrm{mg})$ using dissection techniques with clean 
instruments treated with RNAse Erase (MP Biomedicals, Solon, Ohio) and placed these tissue samples into individual microcentrifuge tubes containing a storage solution (RNAlater; Ambion, Grand Island, New York) to preserve nucleic acids for subsequent analysis (see Nucleic acid analysis section).

For our first experiment, we sought to use a similar calibration method to Clemmesen (1994) to develop a predictive relationship between yellow perch RNA:DNA ratios and somatic growth, which then could be applied to nonlaboratory settings. We used three different feeding rations (low, medium, and high) and three temperatures $\left(11,20\right.$, and $\left.26^{\circ} \mathrm{C}\right)$ to induce different growth rates and subsequently measured the RNA:DNA ratio from the muscle tissue of individuals. We used a full factorial design with three replications per treatment $(n=27$ tank replicates, 54 individual yellow perch). We used a bioenergetics model (Kitchell et al. 1977) to calculate potential temperaturespecific maximum consumption rate and maintenance ration rate (i.e., the amount of daily consumption predicted to result in no gain or loss of mass) to define our three ration treatments. Our high ration level was $150 \%$ of maximum daily consumption, medium ration was $150 \%$ of maintenance consumption, and the low ration was $50 \%$ of maintenance consumption. To account for any mass loss during the starvation periods of acclimation days $2-3$, we took additional length and mass measurements of each experimental yellow perch after this starvation period and before the feeding trial on experimental day 1 . We did not manipulate dissolved oxygen concentrations for this experiment beyond simply injecting sufficient atmospheric air through air stones into each aquarium to maintain normoxic conditions in all experimental chambers and otherwise followed the overall experimental design presented above.

Through our second experiment, we investigated the interactive effects of dissolved oxygen and temperature on young yellow perch consumption, growth and RNA:DNA ratios. Experimental treatments included three temperatures $(11,20$, and $\left.26^{\circ} \mathrm{C}\right)$ and three dissolved oxygen concentrations (2, 5, and 8 $\mathrm{mg} / \mathrm{L}$ ) for the $20^{\circ} \mathrm{C}$ and $26^{\circ} \mathrm{C}$ temperature treatments and four oxygen concentrations $(2,5,8$, and $11 \mathrm{mg} / \mathrm{L})$ for the $11^{\circ} \mathrm{C}$ treatment. During the experiments, we fed yellow perch thawed $M$. relicta ad libitum for $6 \mathrm{~h}$, based on estimated maximum consumption rates from a bioenergetics model (Kitchell et al. 1977). No fish consumed all the food during the 6-h feeding trial. Owing to limited tank space, we repeated this experimental design three times from June to August 2007. For each experimental trial, we included all treatments for a full $3 \times 3(4)$ factorial design with two replicates (i.e., four fish) for every treatment. To adjust for potential mortality loss, we allocated two additional replicate tanks (i.e., four yellow perch) to each of the low oxygen treatments at medium and high temperatures. Thus, an experimental trial consisted of 48 fish distributed among 48 experimental compartments within 24 experimental tanks $(n=72$ tank replicates across three experimental trials). Roberts (2010) evaluated the potential effect of trial week on yellow perch consumption, growth, and RNA:DNA ratios and found no sig- nificant effects. Thus, we combined data across experimental trials for subsequent analyses.

Field collections.-In 2005 and 2007, we collected young yellow perch from various sites in LECB to compare RNA:DNA ratios among areas with hypoxic and normoxic hypolimnia. Sites consisted of 5-km east-west transects within which all sampling was performed. During 2005, we sampled four sites (A, B, D, and $\mathrm{H}$ ) on a monthly basis during June-October (excluding July for which no collections were made; Table 1; Figure 1). The set of sites we sampled varied by month, and we only sampled site B every month (see Table 1 ). Site H varied in depth; thus, given the depth of the thermocline, shallower areas along this site's transect may have experienced normoxic conditions during September, whereas other areas were hypoxic (for further details see, Roberts et al. 2009; Vanderploeg et al. 2009b). During 2007, we sampled LECB twice during hypoxic conditions (August and September). During August, we sampled one stratified hypoxic site (B), one stratified normoxic site (U), and one unstratified normoxic site (T; Table 1; Figure 1). During September, we sampled one stratified normoxic site (SS) and two unstratified normoxic sites (D2 and D3; Table 1; Figure 1).

To quantify abiotic conditions (e.g., temperature and dissolved oxygen), we used vertical casts (measurements at $\sim 0.03$ $\mathrm{m}$ depth intervals) of a Sea-Bird 911 + CTD (i.e., conductivity, temperature, and depth) profiler equipped with a Sea-Bird Electronics 13 dissolved oxygen sensor (Sea-Bird Electronics, Bellevue, Washington). Casts were conducted at the east, west, and midpoint of each site transect at least once per 24-h sampling period. We collected yellow perch at each site with bottom $(7.6 \mathrm{~m}$, semiballoon, 13-mm-stretched-mesh cod liner) and midwater $(9.1 \times 9.1 \mathrm{~m}, 13-\mathrm{mm}$-stretched-mesh cod liner) trawls, which sampled fish from benthic areas and areas above the thermocline, respectively. For analyses, we grouped fish collected by these two different gears together because yellow perch in LECB evidently migrate vertically on a subdaily basis (Roberts 2010) and, hence, would experience the suite of vertical conditions at a particular site. Upon collection, we quickly counted and measured yellow perch TL (to $1 \mathrm{~mm}$ ) and wet mass (to $0.01 \mathrm{~g}$ ). To determine RNA:DNA ratios, we extracted white epaxial muscle tissue $(\sim 40 \mathrm{mg})$ using clean dissection techniques and placed tissue into individual microcentrifuge tubes containing a storage solution (RNAlater) to preserve nucleic acids for subsequent analysis.

Nucleic acid analysis.-We quantified RNA:DNA ratios from experimental and field-collected young yellow perch ranging in size from 100 to $180 \mathrm{~mm}$ TL. White epaxial muscle tissue samples were stored in RNAlater at $4^{\circ} \mathrm{C}$ until analysis (Gorokhova 2005). We measured nucleic acids fluorometrically using a microplate fluorescence reader $\left(\mathrm{FL}_{\mathrm{x}} 800\right.$, Bio-Tek instruments with KCjunior software) and an established protocol for quantifying nucleic acids (Gorokhova and Kyle 2002; Höök et al. 2008). In brief, this method involves extracting nucleic acids into solution, adding Ribogreen, and comparing nucleic 
TABLE 1. Mean habitat characteristics of the sites sampled in Lake Erie's central basin during the summers of 2005 and 2007. Sites are categorized as follows: $\mathrm{H}=$ hypoxic stratified water column, $\mathrm{N}=$ normoxic stratified water column, and $\mathrm{U}=$ unstratified water column. Groupings are based on the presence ( $\mathrm{H}$ or $\mathrm{N}$ )

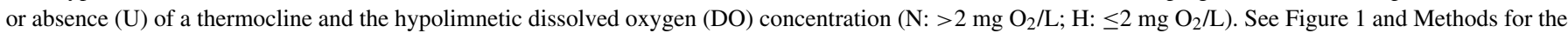
locations and descriptions of the sites. Asterisks note that the depth at site $\mathrm{H}$ varied along a west-to-east transect and a range of depths are presented for this site.

\begin{tabular}{|c|c|c|c|c|c|c|c|c|}
\hline Dates & Site & $\begin{array}{l}\text { Depth } \\
\text { (m) }\end{array}$ & $\begin{array}{c}\text { Epilimnion } \\
\text { temperature } \\
\left({ }^{\circ} \mathrm{C}\right)\end{array}$ & $\begin{array}{l}\text { Epilimnion } \\
\text { DO } \\
\left(\mathrm{mg} \mathrm{O}_{2} / \mathrm{L}\right)\end{array}$ & $\begin{array}{l}\text { Thermocline } \\
\text { depth } \\
\text { (m) }\end{array}$ & $\begin{array}{c}\text { Hypolimnion } \\
\text { temperature } \\
\left({ }^{\circ} \mathrm{C}\right)\end{array}$ & $\begin{array}{c}\text { Hypolimnion } \\
\text { DO } \\
\left(\mathrm{mg} \mathrm{O}_{2} / \mathrm{L}\right)\end{array}$ & Category \\
\hline \multicolumn{9}{|c|}{2005} \\
\hline \multirow[t]{2}{*}{ Jun 17-21 } & B & 23.2 & 17.9 & 8.8 & 10.8 & 8.7 & 10.5 & $\mathrm{~N}$ \\
\hline & $\mathrm{D}$ & 20.5 & 18.3 & 8.8 & 12.0 & 10.2 & 11.1 & $\mathrm{~N}$ \\
\hline \multirow[t]{3}{*}{ Aug $15-18$} & B & 23.2 & 25.0 & 7.1 & 12.8 & 10.3 & 4.6 & $\mathrm{~N}$ \\
\hline & $\mathrm{D}$ & 20.5 & 25.2 & 7.1 & 17.9 & 13.0 & 4.8 & $\mathrm{~N}$ \\
\hline & $\mathrm{H}$ & $14.2(11-21)^{*}$ & 23.3 & 6.6 & 8.0 & 11.7 & 2.7 & $\mathrm{H}$ \\
\hline \multirow[t]{4}{*}{ Sep 17-19 } & A & 20.7 & 21.6 & 6.3 & 14.7 & 11.6 & 1.1 & $\mathrm{H}$ \\
\hline & B & 23.2 & 21.7 & 6.4 & 16.8 & 11.3 & 1.5 & $\mathrm{H}$ \\
\hline & $\mathrm{H}$ & $14.2(11-21)^{*}$ & 21.9 & 6.8 & 14.5 & 15.4 & 0.9 & $\mathrm{H}$ \\
\hline & \multicolumn{8}{|c|}{2007} \\
\hline \multirow[t]{3}{*}{ Aug 27-30 } & B & 24.0 & 23.1 & 7.5 & 15.0 & 11.8 & 2.1 & $\mathrm{H}$ \\
\hline & $\mathrm{U}$ & 13.5 & 23.4 & 7.5 & 11.5 & 20.5 & 4.1 & $\mathrm{~N}$ \\
\hline & $\mathrm{T}$ & 13.0 & 23.9 & 6.6 & & & & $\mathrm{U}$ \\
\hline \multirow[t]{3}{*}{ Sep 17-20 } & D2 & 21.0 & 20.9 & 6.7 & & & & $\mathrm{U}$ \\
\hline & D3 & 17.5 & 20.9 & 6.8 & & & & $\mathrm{U}$ \\
\hline & SS & 18.0 & 21.0 & 6.8 & 18.0 & 18.6 & 4.5 & $\mathrm{~N}$ \\
\hline
\end{tabular}

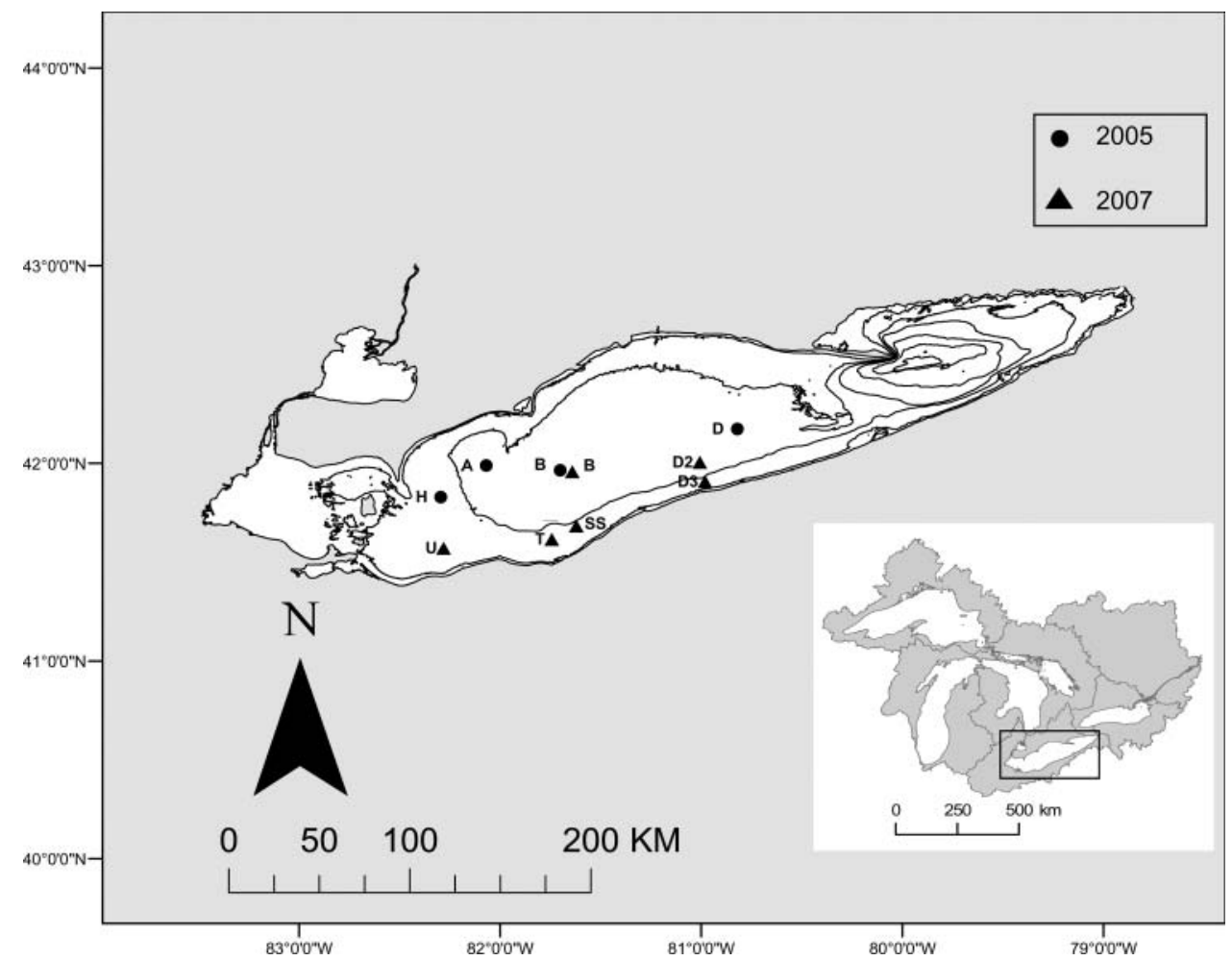

FIGURE 1. Locations of sites sampled in Lake Erie during 2005 and 2007. Lake Erie bathymetry is depicted with 10-m depth contours. 
acid fluorescence between samples and known RNA and DNA standards before and after treatment with RNase. Further details regarding specific working reagents, standards, and controls used are presented in Roberts (2010). To correct for any variation in our standards and working reagents over the 3 years during which our samples were collected and analyzed, we calculated the standard curve ratio $\left(m_{\mathrm{DNA}} / m_{\mathrm{RNA}}\right)$ for each plate as described by Caldarone et al. (2006) and standardized all our RNA:DNA ratios using our overall mean curve slope ratio (mean $\pm \mathrm{SE}=2.54 \pm 0.09$ ).

Data analysis.-To analyze experimental results, we calculated indices of growth and consumption. We quantified mean mass-specific consumption as the mean mass of food consumed during experimental days 3-5 divided by final mass on experimental day 5. Similar to Stierhoff et al. (2009), we used specific growth rate (SGR:\% biomass/d; equation 1) as our measure of growth (Ricker 1975; Houde and Schekter 1981). We determined SGR using the instantaneous growth rate $(G$; equation 2):

$$
\mathrm{SGR}=\left(e^{G}-1\right) \times 100
$$

and

$$
G=\left[\log _{e}\left(W_{f}\right)-\log _{e}\left(W_{i}\right)\right] / \mathrm{d},
$$

where $W_{i}$ is initial mass (measured on experimental day 1), $W_{f}$ is final mass (measured on experimental day 5), and $\mathrm{d}$ is the number of days between measurements. For our second experiment (oxygen and temperature effects), we used measures of fish mass from acclimation day 1 and experiment day 5 . Thus, for our second experiment we calculated growth for a period encompassing a 3 -d starvation acclimation period and five experimental days (i.e., $8 \mathrm{~d}$ total).

Across the size range of yellow perch analyzed, we did not find a significant linear relationship between yellow perch length and RNA:DNA ratio (Figure 2A, B). Thus, we did not include TL as a covariate in our analysis and instead used two-way analysis of variance (ANOVA) to analyze treatment effects. For our second experiment (oxygen and temperature effects), we excluded the high-oxygen by low-temperature treatment from our ANOVA analysis ( $n=66$ tank replicates) to facilitate a balanced design $(3 \times 3)$. Based on ANOVA results, we used post hoc Tukey's pairwise comparisons $(\alpha=0.05)$ to analyze treatment differences.

A goal of our first experiment was to evaluate the ability of RNA:DNA ratios to index growth and thereby describe a predictive relationship. Studies of other species suggest that such relationships are temperature dependent (Buckley et al. 1999). We observed a strong correlation between temperature and RNA :DNA ratio ( $r=-0.88)$, and this temperature effect made it difficult to evaluate the RNA:DNA ratio-growth relationship with a multiple linear regression approach. Instead, we fit a separate ordinary least-squares regression line for each temperature
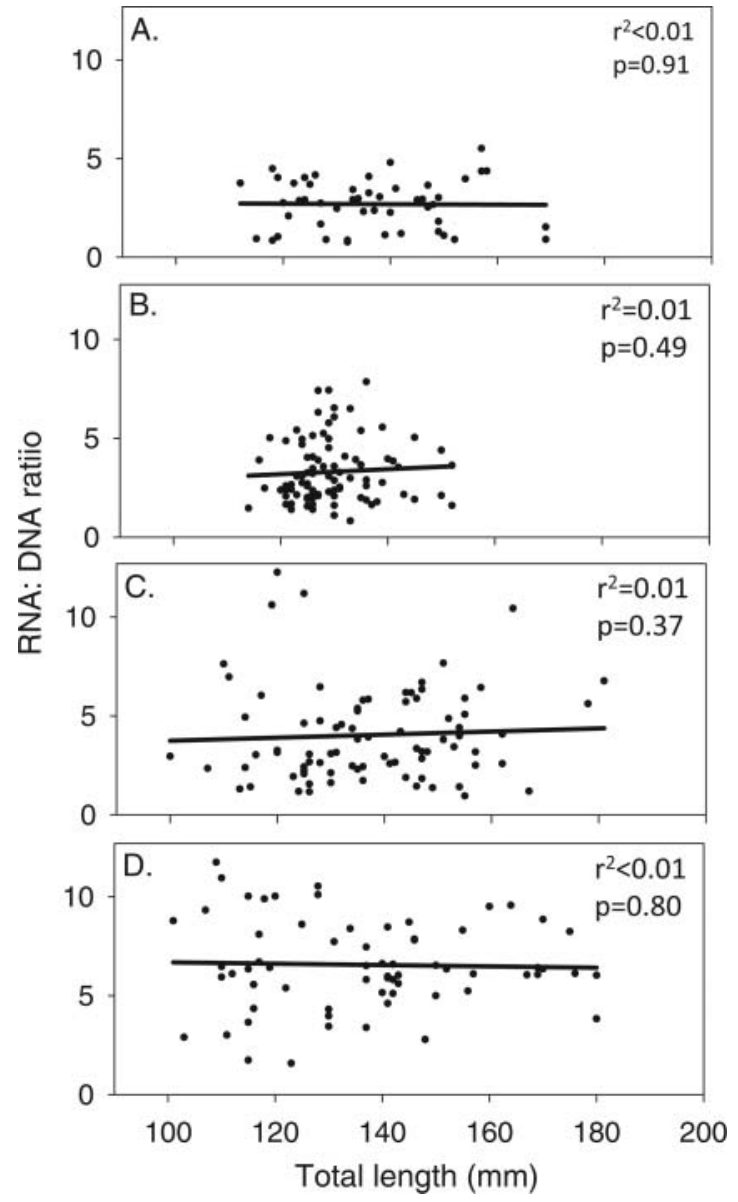

FIGURE 2. The relationship between RNA:DNA ratios and total length (TL) of individual young yellow perch from (A) ration and temperature experiment, (B) dissolved oxygen and temperature experiment, (C) 2005 field samples, and (D) 2007 field samples. Regression statistics related to linear relationships between TL and RNA:DNA ratio presented.

treatment using RNA:DNA ratio as the independent variable and growth as the dependent variable.

To analyze RNA:DNA ratios from field-collected yellow perch we first determined that yellow perch length and RNA: DNA ratios were uncorrelated among individuals collected during 2005 and 2007 (Figure 2C, D). Thus, in analyzing RNA: DNA ratio patterns, we did not include TL as a covariate. Given the unbalanced sampling, i.e., different sites were sampled each month, we used a series of one-way ANOVA with post hoc Tukey's comparisons $(\alpha=0.05)$ to evaluate differences in yellow perch RNA:DNA ratios. We grouped our field-collected yellow perch RNA:DNA ratio data from 2005 and 2007 by month and used two ANOVAs (one for each year) to evaluate coarse temporal patterns. We also compared 2005 and 2007 RNA:DNA ratios by sites (1) within months (four ANOVA for 2005 and two ANOVAs for 2007) to evaluate spatial patterns and (2) among months by site (four ANOVA, one for each site) to evaluate site-specific temporal patterns (2005 only). We corrected all ANOVAs for an unbalanced data set by using type III 
sum of squares. We performed all statistical analyses described herein using SYSTAT 12 software and results were evaluated at $\alpha=0.05$ level of significance.

\section{RESULTS}

\section{Experimental Results}

Through our first experiment, we evaluated consumption, growth, and RNA:DNA ratios across three temperature treatments and three ration treatments. One yellow perch died during the experiment (high-temperature, low-ration treatment), and thus, we ultimately evaluated effects across 26 replicate tanks $(\mathrm{TL}=135.2 \pm 1.6 \mathrm{~mm}[$ mean $\pm \mathrm{SE}]$, mass $=25.6 \pm 1.1 \mathrm{~g})$. Consumption and RNA:DNA ratios were affected by temperature, with high temperatures resulting in higher consumption and lower RNA:DNA ratios (Figure 3). Ration level also affected consumption and growth, with low ration not surprisingly leading to relatively low consumption and growth (Figure 3). The interaction term between temperature and ration was only significant for consumption (Figure 3A). Post hoc pairwise comparisons suggested that within the high-temperature treatment, consumption at low ration was significantly less than that in the
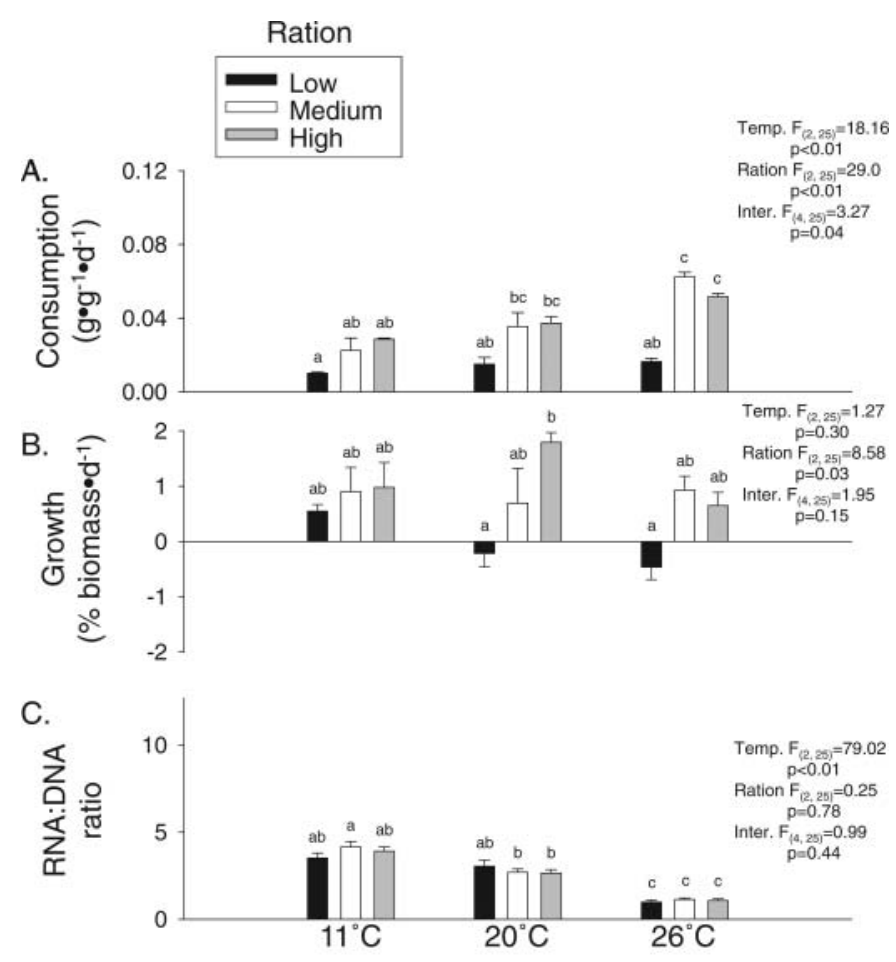

Temperature treatment

FIGURE 3. Results (mean $+\mathrm{SE}$ ) from ration and temperature experiment for each response variable: (A) consumption, $(\mathbf{B})$ growth rate, (C) RNA:DNA ratios. The ANOVA statistics are presented for the two factors (temperature and ration), the interaction between the two factors, and Tukey's post hoc comparison. Different lowercase letters above bars denote significant statistical differences between treatments $(\alpha=0.05)$.

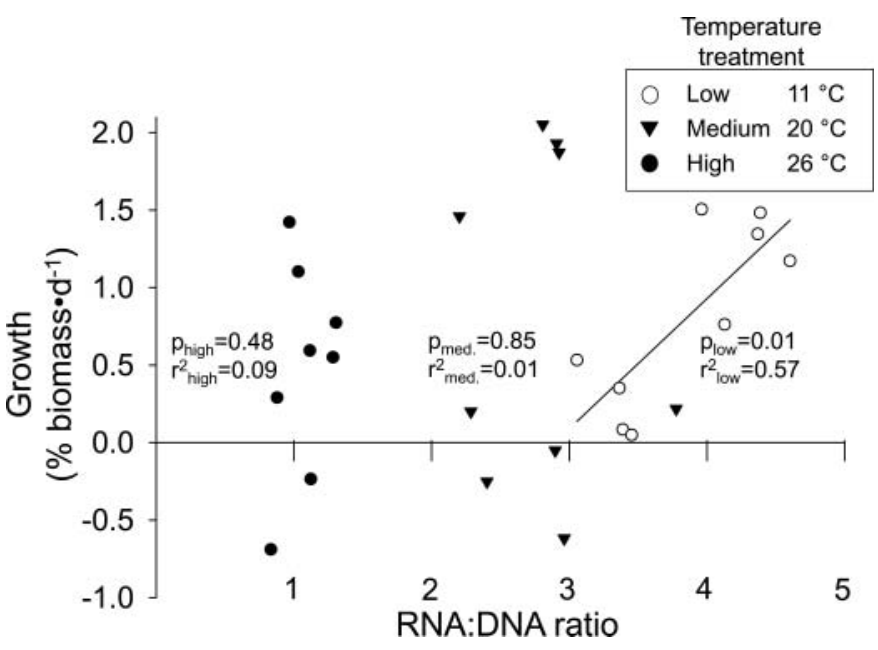

FIGURE 4. Temperature-specific relationships between young yellow perch RNA:DNA ratios and growth rates observed in the experiment examining ration and temperature effects. Symbol type corresponds to each point's temperature treatment. Only significant regression lines $(\alpha=0.05)$ are presented.

medium- and high-ration treatments (Figure 3A). For our low $\left(11^{\circ} \mathrm{C}\right)$ temperature treatment RNA:DNA ratios were a significant predictor of growth (Figure 4). However, no relationship between RNA:DNA ratio and growth was found at $20^{\circ} \mathrm{C}$ or $26^{\circ} \mathrm{C}$ (Figure 4).

Through our second experiment, we evaluated the effects of temperature and dissolved oxygen on yellow perch consumption, growth, and RNA:DNA ratios. We removed eight tank replicates owing to perch mortality and 11 because of nucleic acid contamination, which resulted in 58 replicate tanks for statistical analysis. Consumption, growth, and RNA:DNA ratios of yellow perch $(\mathrm{TL}=129.6 \pm 0.6 \mathrm{~mm}$, mass $=20.6 \pm$ $0.5 \mathrm{~g}$ ) varied across temperature treatments (Figure 5). Consumption was lowest in the low temperature treatment, whereas growth and RNA:DNA ratios were lowest in the high temperature treatment (Figure 5). While RNA:DNA ratios did not vary across dissolved oxygen treatments, temperature and dissolved oxygen interacted to affect both consumption and growth (Figure 5). Dissolved oxygen concentration did not affect growth or consumption in the low temperature treatment; however, in the medium and high temperature treatments, both consumption and growth were lowest in the low dissolved oxygen treatment (Figure 5A, B).

\section{Field Measurements}

Comparisons of RNA:DNA ratios across months during 2005 (with data pooled across sites) demonstrated that nucleic acid indices varied through time (Figure 6A; one-way ANOVA: $\left.F_{2,80}=4.10, P=0.02\right)$, with greater ratios observed during August $(\mathrm{TL}=128.2 \pm 6.1 \mathrm{~mm}$, mass $=27.5 \pm 2.8 \mathrm{~g}, n=$ 32) than June $(\mathrm{TL}=123.1 \pm 2.1 \mathrm{~mm}$, mass $=18.7 \pm 1.3 \mathrm{~g}$, $n=21$ ). We found no differences in RNA:DNA ratios in fish between September $(\mathrm{TL}=145.6 \pm 4.8 \mathrm{~mm}$, mass $=36.3 \pm$ 


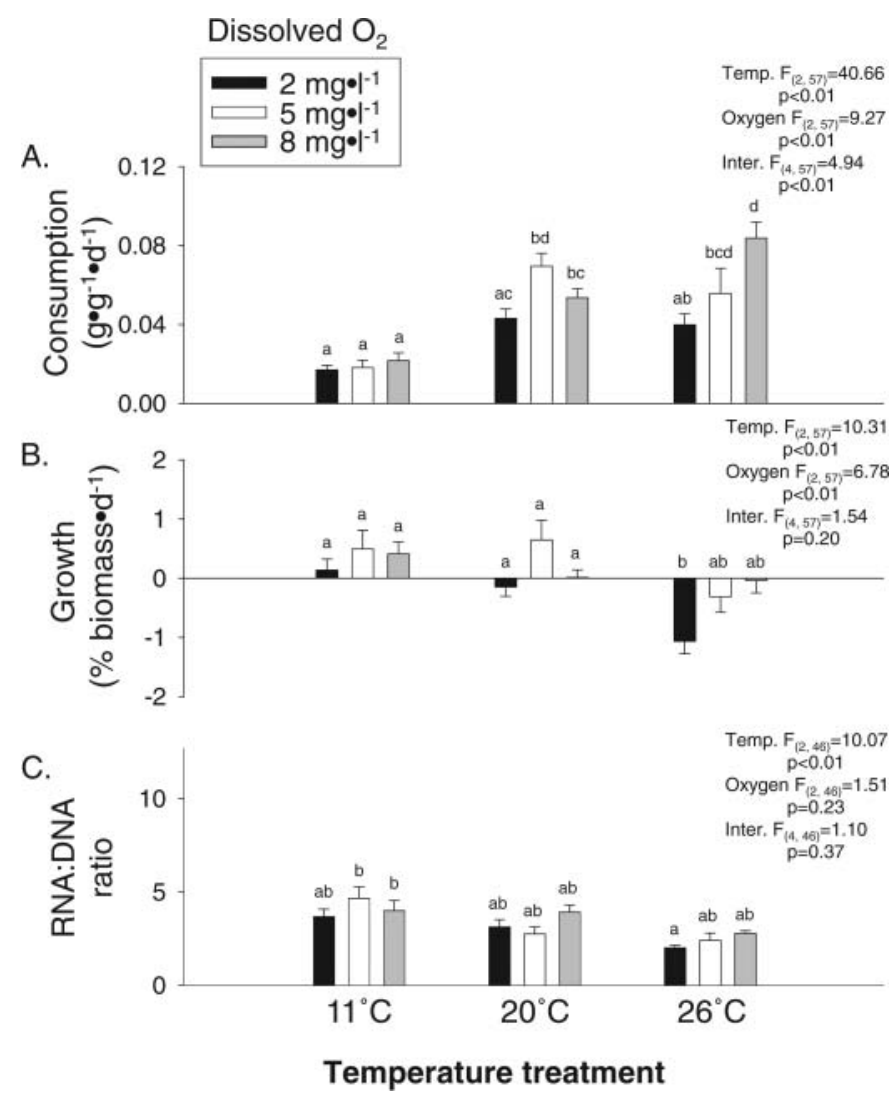

FIGURE 5. Results (mean $+\mathrm{SE}$ ) from dissolved oxygen and temperature experiment for each response variable: $(\mathbf{A})$ consumption, $(\mathbf{B})$ growth rate, $(\mathbf{C})$ RNA:DNA ratio. The ANOVA statistics are presented for the two factors (temperature and dissolved oxygen), the interaction between the two factors, and Tukey's post hoc comparison. Different lowercase letters above bars denote significant statistical differences between treatments $(\alpha=0.05)$.

$3.0 \mathrm{~g}, n=34$ ) and the other months (Figure 6A). During June, the mean RNA:DNA ratio in fish at site $\mathrm{D}$ was less than at site $\mathrm{B}$ $\left(F_{1,20}=7.31, P=0.01\right)$, and during September the mean ratio at site $\mathrm{H}$ was lower than at sites $\mathrm{A}$ and $\mathrm{B}\left(F_{2,27}=16.39, P<\right.$ 0.01; Figure 6B). However, we found no differences in mean RNA:DNA ratio in fish among sites during August $\left(F_{2,31}=\right.$ $1.06, P=0.36$; Figure $6 \mathrm{~B})$. Within-site temporal variation of RNA:DNA ratios was evident at site $\mathrm{D}$, with greater ratios occurring during August than during June $\left(F_{1,24}=6.52, P=0.02\right.$; Figure 6C). There was no difference in RNA:DNA ratios across sample months at sites $\mathrm{B}\left(F_{2,30}=1.88, P=0.17\right)$ or $\mathrm{H}\left(F_{1,16}=\right.$ $1.29, P=0.27$; Figure $6 \mathrm{C}$ ).

During 2007, we collected young yellow perch during August $(\mathrm{TL}=142.0 \pm 5.0 \mathrm{~mm}$, mass $=36.6 \pm 4.8 \mathrm{~g}, n=$ 38) and September $(\mathrm{TL}=140.6 \pm 5.4 \mathrm{~mm}$, mass $=29.3 \pm$ $4.6 \mathrm{~g}, n=26)$ at the height of hypoxic conditions in LECB. We sampled sites with normoxic and hypoxic hypolimnetic conditions during both months (Table 1). We quantified RNA:DNA ratios of 17 yellow perch from hypoxic areas (August: $n=17$, September: $n=0$ ), 12 from normoxic areas (August: $n=4$, September: $n=8$ ), and 35 from unstratified normoxic areas
A.
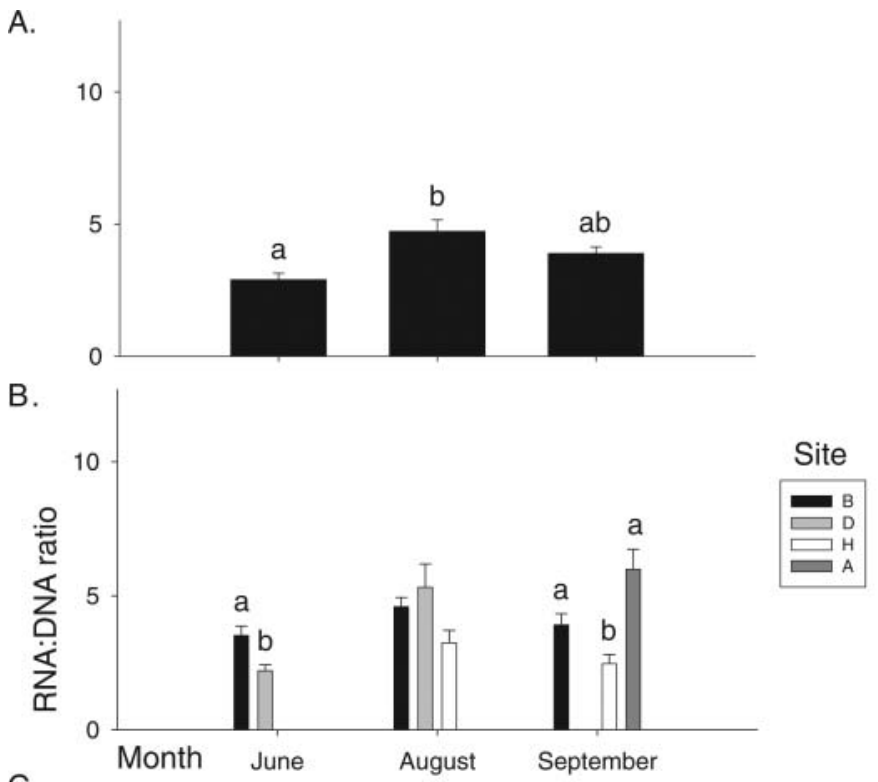

C.

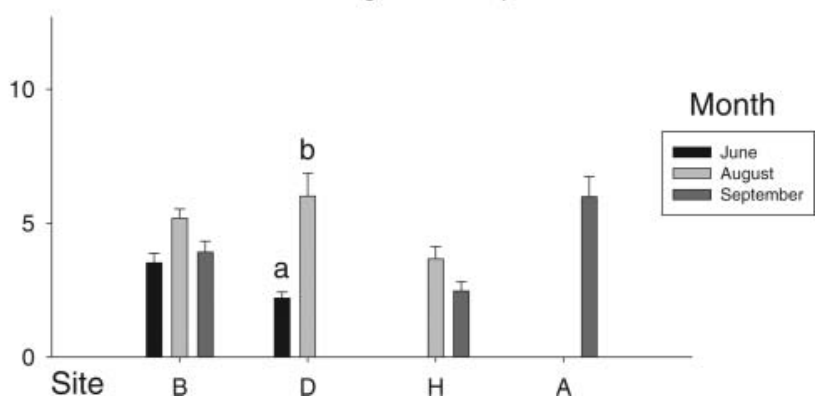

FIGURE 6. Yellow perch RNA:DNA ratios (mean + SE) from Lake Erie's central basin in 2005. Values were compared using ANOVAs with (A) month, (B) sites within months, and (C) sites between months as factors. Different lowercase letters denote significant statistical differences, while the absence of letters or presence of shared letters denotes $P>0.05$. See Figure 1 and Methods for location and description of sites.

(August: $n=5$, September: $n=30$ ). Thus, the power to detect differences between our three habitat types through this analysis was relatively low. Nonetheless, using data grouped across sites with normoxic, hypoxic, and unstratified conditions, we found significantly greater RNA:DNA ratios in yellow perch during August than during September $\left(F_{1,63}=14.03, P<0.01\right.$; Figure 7A). However, during August $\left(F_{2,25}=0.24, P=0.79\right)$ and September $\left(F_{2,37}=1.87, P=0.17\right)$, RNA:DNA ratios did not differ among sites (Figure 7B).

\section{DISCUSSION}

If young yellow perch are unable to avoid low oxygen environments, hypoxia has the potential to negatively affect yellow perch consumption and growth. However, fish are mobile organisms that can sense (Kramer 1987) and avoid potentially hazardous low oxygen conditions. Hence, the effects of the hypoxic hypolimnion in LECB on young yellow perch will probably act both through direct exposure to low oxygen and 


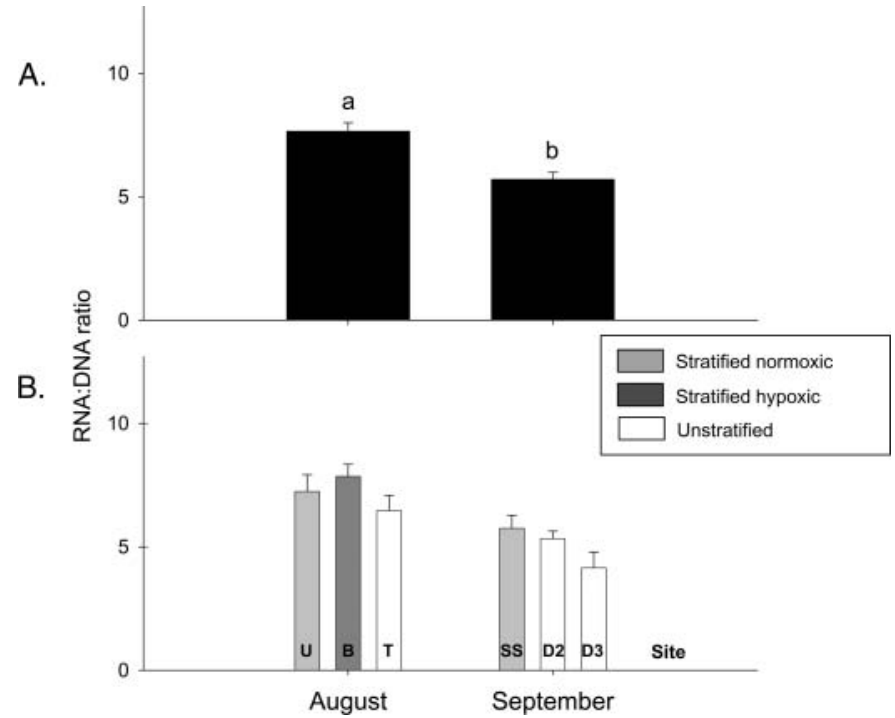

FIGURE 7. Yellow perch RNA:DNA ratios (mean + SE) from Lake Erie's central basin in 2007. Sites were grouped into three categories: hypoxic stratified water column (Hypoxic), normoxic stratified water column (Normoxic), and unstratified water column (Unstratified); values were compared using ANOVAs with (A) month and (B) sites within a month as factors. Different lowercase letters denote significant statistical differences, while the absence of letters or presence of shared letters denotes $P>0.05$. See Figure 1 and Methods for location and description of sites.

through indirect effects, whereby altered behavior may affect thermal habitation and foraging opportunities. Past studies have demonstrated that yellow perch adjust distributions and foraging patterns in response to hypolimnetic hypoxia (Hergenrader and Hasler 1966; Hubert and Sandheinrich 1983; Suthers and Gee 1986). Roberts et al. (2009) confirmed that in hypoxic areas of LECB, yellow perch concentrate above the hypolimnion (also see Vanderploeg et al. 2009b for hydroacoustic evidence). In turn, yellow perch appear to face more energetically costly temperatures and shift from consuming energetically rich benthic macroinvertebrates to zooplankton, which have a lower caloric density (Roberts et al. 2009). However, while our laboratory experiments demonstrated the direct negative effect of hypoxic conditions on consumption and growth of yellow perch, we did not find evidence of hypoxia in LECB indirectly affecting RNA :DNA ratios of young yellow perch. This lack of response to hypolimnetic hypoxia of perch RNA:DNA ratios may arise from young yellow perch behaviorally mitigating potential effects on growth, or simply that RNA:DNA ratios are imperfect indices of growth in this dynamic environment.

Our laboratory experiments support previous investigations and demonstrated a reduction in yellow perch consumption at low dissolved oxygen concentrations, which in turn led to significant (albeit weak) reductions in somatic growth of yellow perch. However, we only observed direct negative effects on consumption and growth at warm temperatures $\left(\geq 20^{\circ} \mathrm{C}\right)$, and no effects of oxygen availability were evident at $11^{\circ} \mathrm{C}$. Note that young yellow perch have a higher thermal optima than do adult perch (Hansen et al. 1997) and this interactive effect between temperature and oxygen concentration may vary among yellow perch life stages. While growth and consumption responded to true hypoxia $\left(2 \mathrm{mg} \mathrm{O}_{2} / \mathrm{L}\right)$, no effects were evident between 5-mg $\mathrm{O}_{2} / \mathrm{L}$ and $8-\mathrm{mg} \mathrm{O}_{2} / \mathrm{L}$ treatments. Carlson et al. (1980) also reported that yellow perch growth decreased when oxygen concentrations approached $2 \mathrm{mg} / \mathrm{L}$ over a 71-d experiment at approximately $20^{\circ} \mathrm{C}$. Brandt et al. (2009) examined the interactive effects of temperature and dissolved oxygen on growth and consumption of juvenile striped bass Morone saxatilis and found that growth and consumption were reduced at dissolved oxygen levels less than $4 \mathrm{mg} / \mathrm{L}$, particularly at higher temperatures. Similarly, Stewart et al. (1967) found that both consumption and growth of largemouth bass Micropterus salmoides declined when exposed to oxygen levels below $3 \mathrm{mg} / \mathrm{L}$. A review and synthesis of studies examining effects of hypoxia on Atlantic cod Gadus morhua, a demersal marine species, suggest that metabolic scope (difference between routine and maximum metabolic rate) is reduced at low oxygen levels and leads to decreased activity and growth (Chabot and Claireaux 2008). Our results are consistent with this review, given that we showed a decrease in growth and consumption of yellow perch at low oxygen conditions, which could potentially be related to physiological processes and reductions in metabolic scope.

These findings also may inform bioenergetics modeling of fish growth and consumption by providing parameters to model dissolved oxygen effects on yellow perch growth and consumption (Hansen et al. 1997). At present, the Wisconsin bioenergetics model for yellow perch (e.g., Kitchell et al. 1977; Hansen et al. 1997) does not include a framework to incorporate the effects of dissolved oxygen. However, others have incorporated its effect by using experimental results to scale the rate of maximum consumption $\left(C_{\max }\right)$ (e.g., Luo et al. 2001; Costantini et al. 2008); this assumes that an individual stressed by hypoxia will feed less. More ideally, we suggest replacing the temperature-dependent equations for $C_{\max }$ with a temperatureand dissolved-oxygen-dependent equation, similar to Cuenco et al. (1985a, 1985b) and Neill et al. (2004). Unfortunately, the temperature range across our experiments was narrower than those used to develop temperature-dependent predictions of $C_{\max }$, so incorporating our dissolved oxygen equation into the existing temperature-dependent model may be more effective. For example, results could be used to identify critical oxygen levels at which $C_{\max }$ starts to decline after which it could be assumed there is a linear decrease of $C_{\max }$ with oxygen concentration, similar to Arend et al. (2011).

While past studies have documented strong relationships between somatic growth rates and RNA:DNA ratios for adult and juvenile fishes, we only found a strong relationship between somatic growth and RNA:DNA ratios at a low $\left(11^{\circ} \mathrm{C}\right)$ temperature. Unlike our study, which lasted for 5-7 d, many previous studies evaluated relationships between growth and RNA:DNA ratios after prolonged periods, e.g., 30-56 d (Grant 1996; Ali 
and Wootton 2003; MacLean and Caldarone 2008). Stierhoff et al. (2009) used RNA:DNA ratios to investigate the growth response of two juvenile estuarine species (weakfish Cynoscion regalis and summer flounder Paralichthys dentatus) to hypoxia in a coastal Delaware bay and found a strong relationship between RNA:DNA ratios and growth after a 7-d period. Stierhoff et al. (2009) also suggested a response of RNA:DNA ratios occurred after only $1 \mathrm{~d}$ without food. We suspect a combination of factors (prolonged effects of initial starvation period, relatively short treatment period [5 d], some negative growth, and small growth differences among our ration treatments) are responsible for the relatively poor fit of the relationship between somatic growth and RNA:DNA ratios at warmer temperatures. While we detected a positive relationship between these two measures of yellow perch growth after only $5 \mathrm{~d}$ at $11^{\circ} \mathrm{C}$, we would expect the strength of this relationship to be more robust across all temperatures with increased exposure time. Moreover, including a starvation period in our experimental design followed by this relatively short period of feeding may have negatively influenced the strength of this relationship. Therefore, our laboratory measures of RNA:DNA ratios may reflect both negative growth associated with the starvation period and the experimental feeding treatments. Nonetheless, the positive relationship between growth and RNA:DNA ratios at low temperatures suggests that RNA:DNA ratios are, at least, qualitatively indicative of relative short-term growth of yellow perch, especially in cool, static environments.

The strong effect of temperature on young yellow perch RNA :DNA ratios makes it less straightforward to use this measure to index growth of fish that experience variable temperatures. Similar to conclusions of previous studies (Buckley 1984; Goolish et al. 1984; Stierhoff et al. 2009), we suggest that it is important to consider temperature when interpreting RNA: DNA ratios of field-collected fish. For example, in areas of Lake Erie with hypoxic hypolimnia, yellow perch consume benthic prey, albeit at a lower rate than under normoxic conditions (Roberts et al. 2009). In these areas, yellow perch frequently (i.e., subdaily) move from warm epilimnetic temperatures to cool hypolimnetic temperatures to feed (Roberts et al. 2009; Vanderploeg et al. 2009b). Thus, even if a temperature-specific relationship existed between the RNA:DNA ratio and somatic growth rate, we are uncertain as to how this relationship would change in response to short-term movements of fish between different thermal strata of the lake. Therefore, to use RNA:DNA ratios to precisely predict short-term growth rates of yellow perch, further research exploring the temperature-specific relationship between this measure and growth is necessary.

While the uncertainty surrounding temperature effects on RNA:DNA ratios somewhat confounds interpretation of nucleic acid ratios of field-collected yellow perch, RNA:DNA ratios of LECB yellow perch show little or no response to hypoxic hypolimnetic conditions. Given that young yellow perch are likely to occupy warmer temperatures at stratified hypoxic sites compared with stratified normoxic sites, a young yellow perch growing at a particular rate at a hypoxic site would be expected to have a lower RNA:DNA ratio than a young perch growing at an identical rate at a normoxic site, where it primarily occupies the cool hypolimnion. Thus, temperature effects on RNA:DNA ratios could be expected to exacerbate differences in nucleic acid ratios between hypoxic and normoxic areas and not mask such differences. Moreover, quantification of RNA:DNA ratios is a well-established approach that has been used extensively to examine approximate short-term growth of field-collected larval (Clemmesen 1994; Höök et al. 2008), juvenile (MacLean and Caldarone 2008), and adult fishes (Aday et al. 2000; Gwak et al. 2003; Glemet and Rodriguez 2007). Hence, the lack of spatial differences in RNA:DNA ratios between hypoxic and normoxic sites suggest that yellow perch are able to behaviorally mitigate potential short-term negative indirect effects of hypoxia on growth. Perhaps by plastically shifting to consume more zooplankton and by undertaking subdaily movements between hypoxic and nonhypoxic layers of the water column to consume benthic invertebrates (Roberts et al. 2009), young yellow perch at hypoxic sites are able to maintain relatively high consumption and growth rates. Also, as demonstrated by Arend et al. (2011), young yellow perch have higher thermal optima than do adult yellow perch and, hence, their maximum growth potential should actually be greater at temperatures observed in the epilimnion and metalimnion, compared with the cold hypolimnion. Finally, Lake Erie's thermocline is dynamic (Rao et al. 2008) and at some of our shallower sites (e.g., site $\mathrm{H}$ ) seiches and upwelling events could lead to rapid changes in bottom oxygen conditions, and thereby intermediately alleviate any potential direct or indirect effects of hypoxia.

While measurements of RNA:DNA ratios of field-collected yellow perch suggest that there are no direct or indirect negative effects of hypolimnetic hypoxia on growth of young yellow perch in LECB, evidence from a variety of other species in multiple systems and other studies of yellow perch in Lake Erie suggest that bottom hypoxia has the potential to negatively affect growth rates. Other studies have shown that hypoxia can both directly and indirectly affect fish growth in freshwater (Aku and Tonn 1997), estuarine (Eby et al. 2005), and coastal marine (Pihl 1994; Petersen and Pihl 1995) systems. Aku and Tonn (1997) demonstrated that the total biomass of ciscoes Coregonus artedi in Amisk Lake, Alberta, increased in response to artificial hypolimnetic oxygenation, but also suggested that individual growth rates decreased owing to resulting densitydependent effects. Petersen and Pihl (1995) used both field and laboratory studies to examine the effects of hypoxia on plaice Pleuronectes platessa and dab Limanda limanda in the Kattegat, an area between the Baltic and North Seas. The field collections of Petersen and Pihl (1995) revealed reduced sizes of both species during hypoxia while laboratory studies found decreases in specific growth rates in response to hypoxia. Eby et al. (2005) used field enclosures to directly observe how periodic hypoxia in the Neuse River estuary influenced growth patterns of juvenile Atlantic croaker Micropogonias undulates. They found 
reduced growth of juvenile estuarine fishes with increased duration and frequency of hypoxic conditions through a variety of pathways (e.g., density-dependent competition and increased benthic prey mortality). Aday et al. (2000) used RNA:DNA ratios to suggest that bluegills Lepomis macrochirus exposed to hypoxic conditions within the lower Atchafalaya River Basin, Louisiana, had lower short-term growth rates (i.e., RNA:DNA ratios) than those in normoxic $\left(>2 \mathrm{mg} \mathrm{O}_{2} / \mathrm{L}\right)$ habitats. However, laboratory studies by Aday et al. (2000) reported no difference in RNA:DNA ratios of bluegills exposed to hypoxic or normoxic conditions.

Previous studies examining seasonal variation in yellow perch growth within the Laurentian Great Lakes suggest that growth and condition increase from summer through September (Diana and Salz 1990; Henderson et al. 2000). However, Roberts et al. (2009) observed no increase in percent dry weight (a close proxy of energy density; Hartman and Brandt 1995) of LECB yellow perch from August to September, which is perhaps indicative of a system-wide hypoxia effect. Under stratified normoxic conditions, young yellow perch in LECB primarily occupy the hypolimnion and feed on benthic invertebrates (Roberts et al. 2009). Thus, a hypoxia-induced shift away from this seemingly preferred growth environment would be expected to negatively affect growth. However, hypoxia also influences distributions of invertebrate prey in Lake Erie (Vanderploeg et al. 2009a, 2009b) and may make zooplankton more available as forage for young yellow perch. In addition, it is plausible that occupation of a deeper, low-light environment during normoxia is partially a predator avoidance strategy for young yellow perch, and while the shift away from this habitat may lead young yellow perch to become more susceptible to predators, this shift may not lead to negative growth consequences.

In conclusion, dissolved oxygen concentrations have the potential to directly influence consumption and growth of yellow perch, particularly at warm temperatures. However, RNA:DNA ratios of yellow perch collected in Lake Erie are rather enigmatic and could suggest that young yellow perch in LECB do not experience hypoxia-induced direct or indirect negative effects on growth. In LECB, hypoxia develops in the cool hypolimnion, and the effects of exposure to low oxygen appear to be less at colder temperatures. Moreover, yellow perch may mitigate the potential negative effects of hypoxia through behavioral and distribution changes. Therefore, it is difficult to document whether short-term consequences of hypoxia exist and it remains equivocal if hypoxia-induced ecological changes scale up to affect population-level dynamics and influence yellow perch production.

\section{ACKNOWLEDGMENTS}

We thank the captains and crew of the RV Laurentian for their tireless work and dedication during our field excursions onto Lake Erie. For their assistance with laboratory and experimental work, we thank Kara Lindelof, Tom Johengen, Kristi Sabo,
Damon Krueger, Solomon David, Greg Jacobs, and Christie Roberts. We especially salute the contributions of Brad Utrup to the design and implementation of our laboratory experiments. We also thank Lizu Wang and Jim Breck from the Michigan Department of Natural Resources' Institute for Fisheries Research for their advice and allowing us to use their facilities. Daisuke Goto, Edward Rutherford, and Earl Werner provided valuable comments on earlier versions of this manuscript. This work was conducted as part of the International Field Years on Lake Erie (IFYLE) program, supported by NOAA-GLERL, NOAA National Sea Grant (to T. Höök), and the U.S. Environmental Protection Agency Great Lakes National Program Office and in part by NOAA Center for Sponsored Coastal Ocean Research grant NA07OAR432000. This manuscript is GLERL-NOAA contribution 1571 and EcoFore Lake Erie publication 09-006.

\section{REFERENCES}

Aday, D. D., D. A. Rutherford, and W. E. Kelso. 2000. Field and laboratory determinations of hypoxic effects on RNA-DNA ratios of bluegill. American Midland Naturalist 143:433-442.

Aku, P. M. K., L. G. Rudstam, and W. M. Tonn. 1997. Impact of hypolimnetic oxygenation on the vertical distribution of cisco (Coregonus artedi) in Amisk Lake, Alberta. Canadian Journal of Fisheries and Aquatic Sciences 54:21822195.

Aku, P. M. K., and W. M. Tonn. 1997. Changes in population structure, growth, and biomass of cisco (Coregonus artedi) during hypolimnetic oxygenation of a deep, eutrophic lake, Amisk Lake, Alberta. Canadian Journal of Fisheries and Aquatic Sciences 54:2196-2206.

Ali, M., and R. J. Wootton. 2003. Correlates of growth in juvenile three-spined sticklebacks: potential predictors of growth rates in natural populations. Ecology of Freshwater Fish 12:87-92.

Arend, K. K., D. Beletsky, J. V. DePinto, S. A. Ludsin, J. J. Roberts, D. K. Rucinski, D. Scavia, D. J. Schwab, and T. O. Höök. 2011. Seasonal and interannual effects of hypoxia on fish habitat quality in central Lake Erie. Freshwater Biology 56:366-383.

Audet, D., and P. Couture. 2003. Seasonal variations in tissue metabolic capacities of yellow perch (Perca flavescens) from clean and metal-contaminated environments. Canadian Journal of Fisheries and Aquatic Sciences 60:269278 .

Brandt, S. B., M. Gerkin, K. J. Hartman, and E. Demers. 2009. Effects of hypoxia on food consumption and growth of juvenile striped bass (Morone saxatilis). Journal of Experimental Marine Biology and Ecology 381:S143-S149.

Buckley, L., E. Caldarone, and T. L. Ong. 1999. RNA-DNA ratio and other nucleic acid-based indicators for growth and condition of marine fishes. Hydrobiologia 401:265-277.

Buckley, L. J. 1982. Effects of temperature on growth and biochemical composition of larval winter flounder Psudopleuronectes americanus. Marine Ecology Progress Series 8:181-186.

Buckley, L. J. 1984. RNA-DNA ratio: an index of larval fish growth in the sea. Marine Biology 80:291-298.

Bulow, F. J. 1987. RNA:DNA ratios as indicators of growth in fish: a review. Pages 45-64 in R. C. Summerfelt, editor. The age and growth of fish. The Iowa State University Press, Ames.

Caldarone, E. M., C. M. Clemmesen, E. Berdalet, T. J. Miller, A. Folkvard, G. J. Holt, M. P. Olivar, and I. M. Suthers. 2006. Intercalibration of four spectrofluorometric protocols for measuring RNA/DNA ratios in larval and juvenile fish. Limnology and Oceanography: Methods 4:153-163.

Carlson, A. R., J. Blocher, and L. J. Herman. 1980. Growth and survival of channel catfish and yellow perch exposed to lowered constant and diurnally fluctuating dissolved oxygen concentrations. Progressive Fish-Culturist 42:73-78. 
Chabot, D., and G. Claireaux. 2008. Environmental hypoxia as a metabolic constraint of fish: The case of Atlantic cod, Gadus morhua. Marine Pollution Bulletin 57:287-294.

Clemmesen, C. M. 1994. The effects of food availability, age or size on the RNA/DNA ratios of individual herring larvae: laboratory calibration. Marine Biology 118:377-382.

Costantini, M., S. A. Ludsin, D. M. Mason, X. Zhang, W. C. Boicourt, and S. B. Brandt. 2008. Effect of hypoxia on habitat quality of striped bass (Morone saxatilis) in Chesapeake Bay. Canadian Journal of Fisheries and Aquatic Sciences 65:989-1002.

Craig, J. K., and L. B. Crowder. 2005. Hypoxia-induced habitat shifts and energetic consequences in Atlantic croaker and brown shrimp on the Gulf of Mexico shelf. Marine Ecology Progress Series 294:79-94.

Cuenco, M. L., R. R. Stickney, and W. E. Grant. 1985a. Fish bioenergetics and growth in aquaculture ponds: I. Individual fish model development. Ecological Modelling 27:169-190.

Cuenco, M. L., R. R. Stickney, and W. E. Grant. 1985b. Fish bioenergetics and growth in aquaculture ponds: II. Effects of interactions among, size, temperature, dissolved oxygen, unionized ammonia and food on growth of individual fish. Ecological Modelling 27:191-206.

Diana, J. S., and R. Salz. 1990. Energy storage, growth, and maturation of yellow perch from different location in Saginaw Bay, Michigan. Transactions of the American Fisheries Society 119:976-984.

Diaz, R. J. 2001. Overview of hypoxia around the world. Journal of Environmental Quality 30:275-281.

Diaz, R. J., and R. Rosenberg. 2008. Spreading dead zones and consequences for marine ecosystems. Science 321:926-929.

Eby, L. A., and L. B. Crowder. 2002. Hypoxia-based habitat compression in the Neuse River estuary: context-dependent shifts in behavioral avoidance thresholds. Canadian Journal of Fisheries and Aquatic Sciences 59:952-965.

Eby, L. A., L. B. Crowder, C. M. McClellan, C. H. Peterson, and M. J. Powers. 2005. Habitat degradation from intermittent hypoxia: impacts on demersal fishes. Marine Ecology Progress Series 291:249-261.

Edwards, W. J., J. D. Conroy, and D. A. Culver. 2005. Hypolimnetic oxygen depletion dynamics in the central basin of Lake Erie. Journal of Great Lakes Research 31:262-271.

Glemet, H., and M. A. Rodriguez. 2007. Short-term growth (RNA/DNA ratio) of yellow perch (Perca flavescens) in relation to environmental influences and spatio-temporal variation in a shallow fluvial lake. Canadian Journal of Fisheries and Aquatic Sciences 64:1646-1655.

Goolish, E. M., M. G. Barron, and I. R. Adelman. 1984. Thermoacclimatory response of nucleic acid and protein content of carp muscle-tissue: influence of growth rate and relationship to glycine uptake by scales. Canadian Journal of Zoology 62:2164-2170.

Gorokhova, E. 2003. Relationships between nucleic acid levels and egg production rates in Acartia bifilosa: implications for growth assessment of copepods in situ. Marine Ecology Progress Series 262:163-172.

Gorokhova, E. 2005. Effects of preservation and storage of microcrustaceans in RNAlater on RNA and DNA degradation. Limnology and Oceanography: Methods 3:143-148.

Gorokhova, E., and M. Kyle. 2002. Analysis of nucleic acids in Daphnia: development of methods and ontogenetic variations in RNA-DNA content. Journal of Plankton Research 24:511-522.

Grant, G. C. 1996. RNA-DNA ratios in white muscle tissue biopsies reflect recent growth rates of adult brown trout. Journal of Fish Biology 48:12231230.

Gwak, W. S., Y. Tanaka, O. Tominaga, T. Tsusaki, and M. Tanaka. 2003. Field evaluation by RNA/DNA ratios on post-release nutritional status of released and wild Japanese flounder Paralichthys olivaceus juveniles. Journal of Experimental Marine Biology and Ecology 293:107-124.

Hansen, P. C., T. B. Johnson, D. E. Schindler, and J. F. Kitchell. 1997. Fish bioenergetics 3.0. University of Wisconsin-Madison Center for Limnology and University of Wisconsin Sea Grant Institute, Madison.

Hartman, K. J., and S. B. Brandt. 1995. Estimating energy density of fish. Transactions of the American Fisheries Society 124:347-355.
Hawley, N., T. H. Johengen, Y. R. Rao, S. A. Ruberg, D. Beletsky, S. A. Ludsin, B. J. Eadie, D. J. Schwab, T. E. Croley, and S. B. Brandt. 2006. Lake Erie hypoxia prompts Canada-U.S. study. Eos, Transactions, American Geophysical Union 87(3):313-315.

Henderson, B. A., T. Trivedi, and N. Collins. 2000. Annual cycle of energy allocation to growth and reproduction of yellow perch. Journal of Fish Biology 57:122-133.

Hergenrader, G. L., and A. D. Hasler. 1966. Diel activity and vertical distribution of yellow perch (Perca flavescens) under the ice. Journal of the Fisheries Research Board of Canada 23:499-509.

Höök, T. O., E. Gorokhova, and S. Hansson. 2008. RNA:DNA ratios of Baltic Sea herring larvae and copepods in embayment and open sea habitats. Estuarine, Coastal, and Shelf Science 76:29-36.

Houde, E. D., and R. C. Schekter. 1981. Growth rates, rations and cohort consumption of marine fish larvae in relation to prey concentrations. Rapports et Procès-Verbaux des Réunions, Conseil International pour l'Éxploration de la Mer 178:441-453.

Hubert, W. A., and M. B. Sandheinrich. 1983. Patterns of variation in gill-net catch and diet of yellow perch in a stratified Iowa lake. North American Journal of Fisheries Management 3:156-162.

Hurlbert, S. H. 1984. Pseudoreplication and the design of ecological field experiments. Ecological Monographs 54:187-211.

Kitchell, J. F., D. J. Stewart, and D. Weininger. 1977. Applications of a bioenergetics model to yellow perch (Perca flavescens) and walleye (Stizostedion vitreum vitreum). Journal of Fisheries Research Board of Canada 34:19221935.

Kramer, D. L. 1987. Dissolved oxygen and fish behavior. Environmental Biology of Fishes 18:81-92.

Ludsin, S. A., D. M. Mason, X. Zhang, S. B. Brandt, M. R. Roman, W. Boicourt, and M. Constantini. 2009. Hypoxia-avoidance by planktivorous fish in Chesapeake Bay: implications for food web interactions and fish recruitment. Journal of Experimental Marine Biology and Ecology 381:S121-S131.

Luo, J. G., K. J. Hartman, S. B. Brandt, C. F. Cerco, and T. H. Rippetoe. 2001. A spatially-sxplicit approach for estimating carrying capacity: an application for the Atlantic menhaden (Brevoortia tyrannus) in Chesapeake Bay. Estuaries and Coasts 24:545-556.

MacLean, S. A., and E. M. Caldarone. 2008. Estimating recent growth rates of Atlantic salmon smolts using RNA-DNA ratios from nonlethally sampled tissues. Transactions of the American Fisheries Society 137:1279-1284.

Neill, W. H., T. S. Brandes, B. J. Burke, S. R. Craig, L. V. Dimichele, K. Duchon, R. E. Edwards, L. P. Fontaine, D. M. Gatlin, C. Hutchins, J. M. Miller, B. J. Ponwith, C. J. Stahl, J. R. Tomasso, and R. R. Vega. 2004. Ecophys.Fish: a simulation model of fish growth in time-varying environmental regimes. Reviews in Fisheries Science 12:233-288.

Pepin, P., G. T. Evans, and T. H. Shears. 1999. Patterns of RNA/DNA ratios in larval fish and their relationship to survival in the field. ICES Journal of Marine Science 56:697-706.

Petersen, J. K., and L. Pihl. 1995. Responses to hypoxia of plaice, Pleuronectes platessa and dab, Limanda limanda, in the south-east Kattegat: distribution and growth. Environmental Biology of Fishes 43:311-321.

Petrosky, B. R., and J. J. Magnuson. 1973. Behavioral responses of northern pike, yellow perch and bluegill to oxygen concentrations under simulated winterkill conditions. Copeia 1973:124-133.

Pihl, L. 1994. Changes in the diet of demersal fish due to eutrophication-induced hypoxia in the Kattegat, Sweden. Canadian Journal of Fisheries and Aquatic Sciences 51:321-336.

Rao, Y. R., N. Hawley, M. N. Charlton, and W. M. Schertzer. 2008. Physical processes and hypoxia in the central basin of Lake Erie. Limnology and Oceanography 53:2007-2020.

Ricker, W. E. 1975. Computation and interpretation of biological statistics of fish populations. Canadian Depart of the Environment, Fisheries, and Marine Science, Ottawa.

Roberts, J. J. 2010. The ecological consequences of hypoxia for yellow perch (Perca flavescens) in Lake Erie. Doctoral dissertation. University of Michigan, Ann Arbor. 
Roberts, J. J., T. O. Höök, S. A. Ludsin, S. A. Pothoven, H. A. Vanderploeg, and S. B. Brandt. 2009. Effects of hypolimnetic hypoxia on foraging and distributions of Lake Erie yellow perch. Journal of Experimental Marine Biology and Ecology 381:S132-S142.

Ryan, P. A., R. Knight, R. MacGregor, G. Towns, R. Hoopes, and W. Culligan. 2003. Fish-community goals and objectives for Lake Erie. Great Lakes Fishery Commission, Special Publication 03-02, Ann Arbor, Michigan.

Smith, T. R., and L. J. Buckley. 2003. RNA-DNA ratio in scales from juvenile cod provides a nonlethal measure of feeding condition. Transactions of the American Fisheries Society 132:9-17.

Stewart, N. E., D. L. Shumway, and P. Doudoroff. 1967. Influence of oxygen concentration on the growth of juvenile largemouth bass. Journal of Fisheries Research Board of Canada 24:475-494.

Stierhoff, K. L., T. E. Targett, and K. Miller. 2006. Ecophysiological responses of juvenile summer and winter flounder to hypoxia: experimental and modeling analyses of effects on estuarine nursery quality. Marine Ecology Progress Series 325:255-266.

Stierhoff, K. L., T. E. Targett, and J. H. Power. 2009. Hypoxia-induced growth limitation of juvenile fishes in an estuarine nursery: assessment of smallscale temporal dynamics using RNA:DNA. Canadian Journal of Fisheries and Aquatic Sciences 66:1033-1047.

Suthers, I. M., and J. H. Gee. 1986. Role of hypoxia in limiting diel spring and summer distribution of juvenile yellow perch (Perca flavescens) in a prairie marsh. Canadian Journal of Fisheries and Aquatic Sciences 43:15621570.

Tardif, D., H. Glemet, P. Brodeur, and M. Mingelbier. 2005. RNA/DNA ratio and total length of yellow perch (Perca flavescens) in managed and natural wetlands of a large fluvial lake. Canadian Journal of Fisheries and Aquatic Sciences 62:2211-2218.

Taylor, J. C., P. S. Rand, and J. Jenkins. 2007. Swimming behavior of juvenile anchovies (Anchoa spp.) in an episodically hypoxic estuary: implications for individual energetics and trophic dynamics. Marine Biology 152: 939-957.

Thomas, P., M. S. Rahman, J. A. Kummer, and S. Lawson. 2005. Reproductive endocrine dysfunction in Atlantic croaker exposed to hypoxia. Pages S249S252 in 13th International Symposium on Pollutant Responses in Marine Organisms. Elsevier Scientific, Alessandria, Italy.

Vanderploeg, H. A., S. A. Ludsin, J. F. Cavaletto, T. O. Höök, S. A. Pothoven, S. B. Brandt, J. R. Liebig, and G. A. Lang. 2009a. Hypoxic zones as habitat for zooplankton in Lake Erie: refuges from predation or exclusions zones? Journal of Experimental Marine Biology and Ecology 381:S108S120.

Vanderploeg, H. A., S. A. Ludsin, S. A. Ruberg, T. O. Höök, S. A. Pothoven, S. B. Brandt, G. A. Lang, J. R. Liebig, and J. F. Cavaletto. 2009b. Hypoxia affects spatial distributions and overlap of pelagic fish, zooplankton, and phytoplankton in Lake Erie. Journal of Experimental Marine Biology and Ecology 381:S92-S107. 